\title{
Does the Market Believe White Knights and Hostile Bidders are acting in Their Shareholders' Interest?
}

\author{
John M. Griffith \\ Old Dominion University \\ Mohammad Najand \\ Old Dominion University \\ Jiancheng Shen \\ Taylor University
}

This study examines why white knights suffer significant losses while their rival hostile bidders experience significant abnormal gains. We address two research questions: 1) Does the market believe that white knights and hostile bidders are acting in their shareholders' interest? 2) Does Tobin's $q$ explain why white knights suffer significant losses and hostile bidders experience significant gains upon the announcement of their bids? The results show that hostile bidders are value-maximizing investors and white knights are not acting in their shareholders' interest. Instead, white knights suffered significant reductions in value and historically have not maximized the wealth of investors.

\section{INTRODUCTION}

Prior empirical research indicates that white knight bidders are a subgroup of bidders who, on average, experience negative abnormal returns upon entry into a contest for corporate control. However, the evidence remains inconsistent regarding bidders in general (Banerjee \& Owers, 1993; Carrol, Griffith, $\&$ Rudolph, 1998; Niden, 1993). The negative abnormal returns indicate that the market does not perceive the white knight's entry/bid as a positive net present value (NPV) investment. Negative abnormal returns for white knights persist over a longer period following entry into bidding contests, which represents a consistent empirical finding over time and across geographies (Smiley \& Stuart, 1985; Sudarsanam \& Mahate, 2006). Hostile bidders have tended to outperform white knight bidders for measurement periods up to three years post-acquisition in the UK and US. The US and UK markets are the most appropriate context for considering the key research questions, and they serve as the market context for much of the empirical research in the academic literature (Papadakis \& Thanos, 2010). The purpose of this study is to determine whether white knight management teams are inefficient because they often make decisions that do not enhance shareholder value. If the white knight's bid is just one more example of overinvestment, then is it prudent to ask whether the current management team should continue controlling the firm? Alternatively, does the value-decreasing bid for the target bring inefficient management to the attention of shareholders, costing management team members their jobs? Buying a company is a highly visible and 
important investment decision that often requires a large outlay of cash. During a takeover, shareholders should take note of managerial performance and replace inefficient management teams. Thus, the first question addressed in our study is whether white knight bidders made good or bad investment decisions. Tobin's q is used to measure the effectiveness of the management. If the mean and median q-ratio for white knight bidders is significantly less than one, then the white knight management has made decisions that did not enhance shareholder value and removing these managers before they make another serious mistake would be in the shareholders' best interest. However, if a company's management is entrenched, it is difficult for shareholders to discourage management from making negative NPV investment decisions. Our results indicate that inefficient management teams are not immediately replaced before or shortly after acquisition. Sudarsanam and Mahate (2006) found that white knight bidders did not replace top management more frequently than hostile bidders or friendly bidders. Kini, Kracaw, and Mian (2004) did not observe a significant relationship between bidder hostility and CEO replacement or stock performance. Thus, shareholders either cannot change corporate leadership or choose not to.

\section{PREVIOUS RESEARCH}

Most studies using a large sample of bidders' returns show a small (up to -1\%) but statistically significant negative cumulative abnormal return (CAR) upon their bid announcement (Eckbo, 2009). However, studies have also shown that a small number of large losses dictates small losses and the median bidder shows a positive abnormal return (Moeller, Schlingemann, \& Stulz, 2005). In seven of nine cases, the initial bidder won control of the target firm while a rival bidder (i.e., a new firm entering the auction after the initial bidder, including white knights) wins in two of nine cases (Betton, Eckbo, \& Thorburn, 2009). Previous research shows that white knight bidders earn negative abnormal returns around the announcement of their entry into the bidding contest (Carol et al.,1998). However, Smiley and Stewart (1985) find that white knights experience no significant abnormal returns. Smiley and Stewart's study is limited to a period (1972-78) when white knights were first used as a defense against hostile acquisitions and missed the takeover boom of the 1980s when the white knight defense tactic became more prominent. In contrast, several studies have found that white knights experience significantly negative abnormal returns when they enter contests. Bradley, Desai, and Kim (1988) group white knights together with all subsequent bidders and find the reduction in bidder returns in multiple bidder contests is due to the negative returns experienced by 'late-bidder' acquirers. Examining white knights specifically, Banerjee and Owers (1992), Niden (1993), and Carrol et al. (1998) find that these bidders experience significantly negative abnormal returns. However, these same studies also find that hostile bidders experience significant positive abnormal returns. Prior research indicates that the market perceives that the initial bids of hostile bidders are in the shareholders' interest while white knights' bids reduce shareholders' value. We begin this study by confirming that our sample is typical, i.e., white knights experience negative abnormal returns while hostile bidders experience significantly positive abnormal returns. Next, we determine whether white knight management teams are inefficient, and if so, whether the highly visible bidding for the target results in the removal of the inefficient management team.

\section{White Knight Entry}

Why does white knight management bid for a target if entering a contest as a white knight usually depresses the stock price? If management is acting in the shareholders' interest, then the white knight may believe that buying the target will enhance shareholder value. In such cases, management believes this combination of bidder and target will lead to a synergy that will more than offset the cost of the acquisition. White knight management may gain this perception because it is often invited to bid by target management, who often have a vested interest in presenting the best possible picture of the target company since a hostile bid is on the table. After consulting with the target, the white knight management may believe it has inside information regarding the potential combination of the two firms. Also, white knight management may be flattered by the knowledge that it has been selected by the target to acquire the company and may overestimate its ability to create synergies (Roll, 1986, hubris argument). Roll's 
(1988) and Thaler's (1988) articles are deployed in empirical merger studies to investigate overconfidence bias or the winner's curse. In addressing the winner's curse, Boone and Mulherin (2008) provide evidence against the winner's curse in corporate takeovers. Competition in and of itself in a corporate auction process does not affect bidder returns. Regarding overconfidence, Malmendier and Tate (2008) show that overconfident managers undertake value-destroying acquisitions.

If management believes the acquisition is a positive NPV project and the market believes the purchase is a negative NPV investment, then either management or the market is mistaken. In some instances, where empirical data are segmented across time, and potentially induced by a shock such as deregulation, research has shown investors may not react correctly in the short run to a merger announcement (Andrade, Mitchell, \& Stafford, 2001). However, long-run event studies have statistical reliability questions, and the preponderance of previous research indicates the market is a good predictor of the ultimate success of acquisition (Kaplan \& Weisbach, 1992). Thus, if management believes the investment is in shareholders' interest, management is mistaken. If management is relatively inexperienced or inefficient, then the acquisition attempt may be considered an honest mistake, even if a large highly visible error, or an aberration in an otherwise consistent record of investing in positive NPV projects.

Alternatively, white knight management may be inefficient in the sense that it may not consistently make decisions in the shareholders' interest. White knight management teams may not have a strong incentive to act in the shareholders' interest. Banerjee and Owers (1993) find the white knight compensation packages have a lower percentage of options and stock appreciation rights than those of hostile bidders. Thus, the interests of management are less aligned with those of shareholders. Banerjee and Owers (1992) indicate that white knight managers may not take the same care and diligence in assessing the value of the bidder-target combination as other types of bidders, and they find that the average number of days between the hostile bid and the white knight bid is only 28 days, which indicates that white knights may bid hastily. Thus, we believe it important to consider that white knight managers could be acting in their self-interest when entering into control contests to increase the firm's size. By increasing the size of the firm, management expands its power and compensation base. When analyzing the executive compensation of Standard and Poor's 500 companies, Ciscel and Carroll (1980) find that cash compensation and size are positively correlated, while Banerjee and Owers find that the compensation of white knight managers is largely cash-based. Additionally, Wright, Kroll, and Elenkov (2002) find that when weaker monitoring characterizes a firm, an increase in the firm's size via acquisition is associated with an increase in executive compensation. Thus, white knight managers may bid for the target to increase the firm size and therefore enhance their self-interest. Based on prior research, we conclude that white knight management teams may be inefficient.

We cannot determine why white knight management teams bid for the target, and management may be considered to have simply made an honest mistake in its bid for the target if management has previously made decisions that enhance shareholder wealth. We examine Tobin's $q$ as a measure of managerial performance in the year before the acquisition. Tobin's $\mathrm{q}$ indicates whether white knight management has made investment decisions that enhance shareholder wealth. The bid for the target can be considered an aberration if it occurs in an otherwise consistent record of making positive NPV decisions. However, if Tobin's $\mathrm{q}$ indicates that white knight management is inefficient and has historically made negative NPV investment decisions, then we consider the bid for the target another bad investment decision. Managerial efficiency is an analogous construct to managerial ability (MA) as quantified by Demerjian, Lev, and McVay (2012). MA is a scaled measure associated with sales growth realized from value generating investments. Demerjian, Lev, and McVay's a priori expectation is to observe a positive association with Tobin's q, and they find an association indicating a plus-one standard deviation on the MA scale with a $10.6 \%$ higher Tobin's q.

\section{Tobin's q}

We use Tobin's q-ratio, which is the ratio of the market value of the firm's assets to the replacement cost of those assets, to determine whether white knight management teams have overinvested. A Tobin's 
q greater than one indicates the "going-concern" value of the firm exceeds the current cost of the assets necessary to generate cash flow. If the value of the firm is divided into assets-in-place and growth opportunities, then a market value greater than the replacement value indicates that the firm has invested in positive NPV projects. A Tobin's q less than one indicates that the firm's current projects and future growth opportunities have negative NPVs. Q is an increasing function of the firm's current and anticipated projects under existing management and a measure of managerial efficiency (Lang, Stulz, \& Walkling, 1989, 1991). Although prior research has not explicitly addressed white knights and hostile bidders, the q value has been used as a measure of managerial efficiency (Hasbrouck, 1985; Lang et al., 1989, 1991; Servaes, 1991; Lang \& Stulz, 1994) when examining bidders' and targets' returns. Lang et al., 1989, 1991 and Lang and Stulz (1994) find a direct relationship between well-managed bidders (q > 1) and gains to bidders in successful tender offers and indicate that bidders with the greatest gains occur for high q bidders, who earn approximately $10 \%$ while low q bidders present losses of approximately $5 \%$. Servaes confirms Lang, Stulz, and Walkling's results and finds that the relationship holds for mergers as well as tender offers. Lang, Stulz, Walkling examine the relationship between cash flow and Tobin's q and conclude that firms with high cash flows and low q ratios have lower abnormal returns, thus implying that these firms are more likely to engage in acquisitions that are not in the shareholders' interest.

\section{DATA AND METHODOLOGY}

We used several sources to identify white knights and hostile bidders. This work contributes to the literature by assembling a 39-year sample of tightly defined white knight contests. A list of white knight contests is compiled for the period 1978-2016. The bidder must meet the following two criteria to be classified as a white knight: 1) Target management must initially reject the unsolicited bid, thus making the initial bidder a hostile bidder; and 2) the white knight's bid is a friendly bid coming after the announcement of a hostile bid to acquire control of the target.

We find a total of 782 white knight contests that meet these strict requirements. We use the Wall Street Journal, the Dow Jones News Wire, and the Lexis/Nexis Business News Service to find the history of each contest. We crosscheck the announcement dates in the Wall Street Journal with those in the Dow Jones News Wire and the Lexis/Nexis Business News Service. We use the earliest announcement date as the event date. We discover that of these 782 contests, certain white knights, and hostile bidders were private firms without publicly available data. A number of the 631 contests have sufficient publicly available data for both white knights and hostile bidders.

The set of 631 white knight firms consists of 570 exchange-listed firms and 61 over-the-counter firms, and 481 of these white knights successfully acquired their target. The market value of equity for the white knight firms ranges from $\$ 51$ million to $\$ 187.24$ billion, with a mean market value of $\$ 15.6$ billion. Interestingly, the composition of the set of 631 hostile bidders is 450 exchange-listed firms and 181 NASDAQ firms. Only 104 hostile bidders were successful in their pursuit of the target, which indicated that using white knights is an effective defense tactic. The hostile bidders' market value of equity ranges from $\$ 30.00$ million to $\$ 97.1$ billion, with a mean market value of $\$ 14.2$ billion.

To calculate abnormal returns, we use the Generalized Autoregressive Conditional Heteroscedastic (GARCH) approach (Engle (1982) and (Bollerslev (1986)). Corhay and Rad (1996), Engle (2001), and Brockett, Chen, and Garven (1999) discuss the potential benefits of GARCH estimations, and their approach considers the well-documented fact that asset returns show volatility clustering. This often-used model allows for variance of the regression to change over time. We use a single factor model with $\operatorname{GARCH}(1,1)$ errors to estimate the market model,

$R_{j t}=\alpha_{j}+\beta_{j} R_{m t}+\varepsilon_{j t}$, 
where $\varepsilon_{j t} \mid \psi_{t-1} \sim\left(0, h_{j t}\right)$ and $\psi_{t-1}$ denotes all information available at time $t-1$. The conditional variance

$h_{j t}=\omega_{j}+\delta_{j} h_{j t-1}+\gamma_{j} \varepsilon_{j t-1}^{2}$,

where $\omega_{j}>0, \gamma_{j} \geq 0$, and $\gamma_{\mathrm{j}}+\delta_{j}<1$. The parameters are estimated by the maximum likelihood method.

The parameters of this single index market model are estimated using 200 daily returns over the period beginning 210 days before the announcement of the takeover and ending 11 days before the announcement. CARs are calculated based on a seven-day window $(-3,3)$, and the entire contest extends from the announcement of the entry until the bidder wins the contest or announces its withdrawal. Bootstrap tests are used to test the significance of the returns over the entire contest period because of the long horizon (Kothari \& Warner (1997). Ang and Zhang (2004) demonstrate that such a bootstrapping procedure has good statistical power at horizons of 1 year or less, which is suitable for our return measurement period.

In addition to abnormal percentage returns, we use abnormal dollar returns through the methodology presented in Dennis and McConnell (1986). We observe that when the bidder is substantially larger than the target, the price increase in the target corresponds to a small gain/loss by the acquirer, and the loss is hidden in the bid/ask spread and in the noise of daily return volatility (Roll, 1986). We calculate the dollar amounts of abnormal returns based on an n-day market-adjusted cumulative abnormal returns (\$CAR).

$$
\$ C A R=n \text {-day } C A R * \text { Price on day }(\mathrm{t}-1-1) * \text { number of shares }
$$

We follow the method of Perfect and Wiles (1994) to estimate the q ratios for each firm.

$$
\text { Tobin's q }=\frac{\text { Market Value }(\text { Equity }+ \text { Debt }+ \text { Preferred Stock })}{\text { Replacement Value(Plant }+ \text { Equipment }+ \text { Inventories })}
$$

The market value of the firm is the sum of the year-end market values of the bidder's common equity, debt, and preferred stock. The year-end value of the common equity is the number of shares outstanding at year-end multiplied by the year-end stock price. Because preferred shares trade infrequently, we find the market value of the preferred stock by capitalizing the total preferred dividends by the Standard and Poor's preferred stock yield index. The market value of short-term debt is its book value. Perfect and Wiles (1994) describe in detail the complex procedure for estimating the market value of long-term debt. Researchers, including Fich and Shivdasani (2006), repeat this procedure several times in the literature.

The replacement cost of the bidders' assets is estimated using

$$
\mathrm{RC}_{\mathrm{t}}=\mathrm{TA}_{\mathrm{t}}+\mathrm{RNP}_{\mathrm{t}}-\mathrm{HNP}_{\mathrm{t}}+\mathrm{RINV}_{\mathrm{t}}-\mathrm{HINV}_{\mathrm{t}}
$$

where $\mathrm{TA}_{\mathrm{t}}$ is the book value of total assets in year $\mathrm{t} ; \mathrm{RNP}_{\mathrm{t}}$ is the bidder's replacement cost of the net plant in year $t ; H_{N P}$ is the historical book value of the net plant in year $t$; $\mathrm{RINV}_{\mathrm{t}}$ is the estimated replacement value of inventories in year $\mathrm{t}$; and $\mathrm{HINV}_{\mathrm{t}}$ is the historical book value of inventories in year $\mathrm{t}$. Perfect and Wiles (1994) provide a more detailed explanation of the estimation procedures for these variables. The data required to calculate the q ratios are obtained from Research Insight, 1978-2016. 


\section{MANAGERIAL INEFFICIENCY}

We begin the analysis by confirming that the white knights in our sample experience negative abnormal returns when they announce their entry into a control contest and hostile bidders experience positive abnormal returns. The results are consistent with previous research. Schwert (2000) uses a return measurement window of -63 days to +126 days around the initial bid in addition to the measurement window deployed in this paper to measure bidder returns. Schwert does not find a significant negative relationship between unsolicited bidder's CAR but does find a negative and significant association between a bid for a firm already in play (i.e., negotiated or white knight bidder) and the bidder's stock CAR. Table 1 contains the measures of abnormal returns. Hostile bidders experience a statistically significant cumulative abnormal gain over the three days surrounding their initial bid of $2.97 \%$, or a significant mean dollar gain of $\$ 37.10$ million. White knights experience a statistically significant loss of $4.79 \%$ or a significant dollar loss of $\$ 158.32$ million. These results are consistent with prior research.

The average Tobin's q measured before the acquisition attempt is 0.78 for white knights (Table 1), and this value is significantly less than one using a standard t-test as well as the Wilcoxon signed rank test. These findings indicate that white knights were overinvesting before the contest and making negative NPV decisions, and the going concern value of the company is less than the replacement value. In this sense, white knight management teams are inefficient and have made investment decisions that were not in the shareholders' interest. The bid for the target is just one more negative NPV investment decision in a long line of value-decreasing investment decisions.

In contrast, hostile bidders have an average q-ratio of 1.10 , which is not significantly different from one, thus indicating that the managers of hostile bidders are generally efficient. The positive abnormal returns indicate that the market believes that the managers of hostile bidders are acting in the shareholders' best interest with a positive NPV investment. Based on the average q for the two groups, we believe that white knight managers overinvest while hostile bidders do not. White knights have negative abnormal returns while hostile bidders have positive abnormal returns when they initially bid for the target. These results suggest that the market's response to the two group's bids is related to managerial efficiency.

TABLE 1

WHITE KNIGHT AND HOSTILE BIDDER RETURNS

\begin{tabular}{|l|c|c|}
\hline & White Knights & Hostile Bidders \\
\hline \$ CAR & & \\
Mean & $-158.32 * * *$ & $37.10^{* * *}$ \\
Median & -83.41 & 14.87 \\
Standard Deviation & 348.88 & 84.73 \\
Maximum & $1,321.68$ & 933.84 \\
Minimum & $-3,281.60$ & -271.93 \\
\% CAR & $-4.79 * * *$ & $2.97 * * *$ \\
Tobin's q & & 1.0971 \\
Mean & $0.7769^{* * *}$ & 0.9814 \\
Median & $0.5981^{* * *}$ & Office Hours: \\
& & M-R 9:30-10:30 AM \\
& & 631 \\
\hline
\end{tabular}

Journal of Accounting and Finance Vol. 18(8) 2018 


\section{White Knights Who Enhance Shareholder Wealth}

Table 2 provides a comparison of abnormal dollar returns for white knights with q values greater and less than one. Although the 3-day abnormal returns for both groups are negative, bidders with q values less than one lose more than firms whose q values are greater than one, and the difference is statistically significant using a standard t-test with unequal variances as well as the nonparametric Mann-Whitney test (Mann \& Whitney, 1947). Of the 631 white knights, 210 have q values equal to or greater than one, and 421 have q ratios less than one. Of the 210 white knights with q values equal to or greater than one, only 67 firms have positive abnormal dollar returns, while 143 have negative abnormal returns. The average 3day positive abnormal dollar return for the 67 firms is $\$ 394.80$ million, which is statistically significant (Table 3). The average 3-day negative abnormal return for the 143 firms is a $\$ 222.60$ million loss, which is statistically significant. Of the 210 white knights with management teams that ordinarily make investment decisions that enhance shareholder wealth, only 67 made positive NPV bids. More than twothirds of the white knight management teams overbid for the target. Therefore, white knight management occasionally overestimates the value of the target. These managers who ordinarily act in the shareholders' interest pursue a negative NPV project thinking it is a positive NPV opportunity. Acquisitions ordinarily require a large dollar cash outflow and are often reported by the news media, particularly if they involve a hostile bid. The decision-makers in the 143 firms that ordinarily make positive NPV decisions make investment decisions that are not in the shareholders' interest. Because damaging their reputation as efficient managers with such a highly visible decision is not in the management team's best interest, we believe that the management of these 143 firms mistakenly believed the acquisition was a profitable investment (Demerjian, 2012).

Inexperienced executives may be more likely to overestimate the value of the target. Often, the targets of hostile bidders actively solicit other more acceptable bidders. Aggressively emphasizing the more positive aspects of their company to potentially friendly bidders is in target management teams' interest, and a favorable target management presentation may more easily influence inexperienced bidders. To determine whether these bidding firms have relatively inexperienced top management teams, we examined Standard and Poor's Register of Corporations, Directors, and Executives for the names of executives at the level of president and above for each white knight management team in the three years before and three years following the year of the acquisition contest. The number of white knights with the same top executive in each of the six years surrounding the contest year is provided in Table 4. Of the 631 firms, 536 firms (85\%) had the same top executive in the year before the contest and the year of the contest, indicating that these executives had at least one year of experience in the leadership role. Moreover, $78 \%$ of the firms we examined had CEOs with at least two years of experience, and $69 \%$ had CEOs with at least three years of experience in a leadership role. Thus, the white knight bidders were not inexperienced executives.

White knights are generally inefficiently managed firms whose managers commonly overbid for the target, thus making the acquisition a negative NPV project, whereas hostile bidders are well-managed firms whose managers initially offer a price for the target firm that makes the investment potentially profitable. White knights are slightly more likely to replace top executives in the year before an acquisition (Table 4). However, these replacements seem to come from the firms' number two spot, as shown in Table 5. Furthermore, significant differences are not observed in the experience levels of the hostile bidder or white knight CEOs.

In addition to examining the experience levels of white knights as a group, we also found it informative to examine the experience levels of the subset of white knights whose q values are greater than one. Could relative inexperience explain why these managers who ordinarily make positive NPV decisions overbid for the target? Of the 143 firms with efficient management teams who bid as white knights and experienced losses, four firms elected their top executive in the contest year, and eight had a top executive newly appointed the year before the contest. All twelve executives were new to the top position but not new to the company. Thus, firms with negative NPV investment decisions did not appear to have inexperienced management or management unfamiliar with the company and its personnel. 
Of the 143 white knights, 93 made a single offer that was accepted by the target management, and the hostile bidder made no counteroffer. Therefore, these firms had no opportunity to withdraw after their initial bid and eliminated any possibility to reassess an overly optimistic assessment of the target firm value. Of the remaining 50 white knights, 22 withdrew from competition, and 18 made multiple bids or otherwise indicated their willingness to do so. Eighteen firms continued to bid for the targets even after observing an adverse market response to their initial offer. However, over $40 \%$ of the firms that had an opportunity to withdraw from competition after observing an adverse market reaction did so. Thus, management teams may overestimate the value of the target.

TABLE 2

\section{COMPARISON OF ABNORMAL DOLLAR RETURNS STRATIFIED BY BIDDER CLASS and TOBIN'S Q}

\begin{tabular}{|l|c|c|c|}
\hline & $\mathbf{q}>\mathbf{1}$ & $\mathbf{q}<\mathbf{1}$ & $\begin{array}{c}\text { Mean Difference } \\
\text { (High q-Low q) }\end{array}$ \\
\hline $\begin{array}{l}\text { Hostile Bidders (HB) } \\
\text { Mean \$ CAR }\end{array}$ & $62.17 * * *$ & -1.63 & $63.80 * * *$ \\
Median \$ CAR & $22.19^{* * *}$ & 0.60 & \\
Number (+,-) \$ CAR & $(265,75)$ & $(154,137)$ & $266.75^{* * *}$ \\
White Knights (WK) & & $-288.39 * * *$ & \\
Mean \$ CAR & -21.64 & $-94.52^{* * * *}$ & \\
Median \$ CAR & $-46.97^{* *}$ & $(28,393)$ & \\
Number (+,-) \$ CAR & $(67,143)$ & $286.76^{* * *}$ & \\
Mean Difference & $83.81^{* * *}$ & & \\
(HB - WK) & & & \\
\hline
\end{tabular}

${ }^{1}$ The mean difference between the hostile bidder and white knight dollar CAR is statistically significant using a t-test assuming unequal variance as well as a nonparametric Mann-Whitney test. ${ }^{* * *},{ }^{* *}$, and ${ }^{*}$ denote statistical significance at the $1 \%, 5 \%$ and $10 \%$ levels, respectively.

TABLE 3

COMPARISON OF WHITE KNIGHT ABNORMAL DOLLAR RETURNS STRATIFIED ACCORDING TO RETURNS and TOBIN'S Q

\begin{tabular}{|l|l|l|c|}
\hline & $\mathbf{q}>\mathbf{1}$ & $\mathbf{q}<\mathbf{1}$ & $\begin{array}{c}\text { Mean Difference } \\
\text { (High q- Low q) }\end{array}$ \\
\hline +CAR & $394.60^{* * *}$ & $87.60^{* *}$ & 307.00 \\
Mean \$ CAR & $198.40^{* * *}$ & $43.6^{* *}$ & \\
Median \$ CAR & 67 & 28 & \\
Number of Bids & & & \\
-CAR & $-222.66^{* * *}$ & $-503.13 * * *$ & $280.47 *$ \\
Mean \$ CAR & $-82.52^{* * *}$ & $-251.30^{* * *}$ & \\
Median \$ CAR & 143 & 393 & \\
Number of Bids & $617.26^{* * *}$ & $590.73 * * *$ & \\
Mean Difference & & \\
\hline
\end{tabular}

$* * *, * *$, and $*$ denote statistical significance at the $1 \%, 5 \%$ and $10 \%$ levels, respectively.

\section{Inefficient Management Teams: White Knights}

Of the 421 white knights with q ratios less than one, 28 firms have positive abnormal dollar returns while 393 have negative abnormal dollar returns. The average 3-day abnormal return for the 28 firms with positive CAR is statistically insignificant while the average abnormal dollar return for the 393 firms with negative CARs is a significant average loss of $\$ 503.13$ million. The average loss for firms with q values 
greater than one is significantly less than the loss for firms with q values less than one. The evidence is consistent: firms with managers who are inefficient or have not acted in shareholders' interests when they bid for a target are considered white knights.

Since acquisitions are highly visible investment decisions that often require large dollar outlays, we seek to determine whether entry into the contest draws investors' attention to an inefficient management team. If so, do investors replace these decision makers? Table 4 shows the number of CEOs not replaced in the years following the acquisition (Year $t$ ) for all white knights. Of the 631 firms, $12 \%$ did not have the same top executive one year after the acquisition, $18 \%$ had new top leadership two years after, and $25 \%$ of the firms had a new top executive three years following the acquisition. We find a tendency to replace the top executive over time, although whether the change is due to managerial inefficiency exacerbated by a value-decreasing acquisition has not been clarified. The absence of a clear association between a value-decreasing acquisition and managerial turnover is consistent with Sudarsanam and Mahate (2006). If the number two executive replaces the top executive, then the inefficient management "team" was likely not replaced because of managerial inefficiency. Top executives tend to be replaced from the number two spot as shown in Table 5. In the year following the acquisition, only 15 firms had new top executives who were not one of the top two executives in the year of the acquisition. Thus, the replacement of the top executive likely is not related to managerial inefficiency or a value-decreasing acquisition that draws shareholders' attention to the relative inefficiency of the management team.

We reinforce this conclusion by conducting a comparison of management retention between white knights and hostile bidders. The percentage of white knight management teams that are retained does not significantly differ from that of hostile bidder management (Tables 4 and 5), although hostile bidders initially make value-increasing investment decisions. Thus, a highly visible significantly value-decreasing investment decision likely results in top managerial replacements among white knight firms.

Although white knights making negative NPV investments dominate the information in Table 4 and Table 5, the management teams of some of these firms make acquisition decisions in the shareholders' interests. We examine executive replacements by value-increasing and value-decreasing acquisition decisions and managerial efficiency (Table 6). A top executive who is different from the prior year is a top executive replacement. We find that for white knights with inefficient management $(q<1)$ and that made a highly visible value-decreasing investment decision $(\mathrm{CAR}<0)$ in the two years following the acquisition, $55(14 \%)$ of the 393 white knights replaced the top executive in the two years after the acquisition. Of these replacements, $24(6 \%)$ come from outside the existing management team. Similarly, in the three years after the acquisition, $71(18 \%)$ of the 393 white knights replaced the top executive. Firms hired $24(6 \%)$ of the replacements from outside. These findings are consistent with entrenched management (Kini, Kracaw, \& Mian, 2004).

TABLE 4

BIDDERS WITH THE SAME TOP EXECUTIVE IN YEAR $t$ and YEARS $t-3$ to $t+3$

\begin{tabular}{|c|c|c|c|c|c|}
\hline & \multicolumn{2}{|c|}{ White Knights } & \multicolumn{2}{|c|}{ Hostile Bidders } & \% Difference \\
\hline & $\mathbf{N}$ & $\%$ & $\mathbf{N}$ & $\%$ & $\%$ \\
\hline $\mathbf{t}-\mathbf{3}$ & 430 & $68 \%$ & 495 & $78 \%$ & $-10 \%$ \\
\hline $\mathbf{t}-\mathbf{2}$ & 489 & 78 & 551 & 87 & -9 \\
\hline$t-1$ & 536 & 85 & 607 & 96 & $-11 * *$ \\
\hline $\mathbf{t}+\mathbf{1}$ & 551 & 87 & 580 & 91 & -4 \\
\hline$t+2$ & 513 & 81 & 542 & 86 & -5 \\
\hline $\mathbf{t}+3$ & 469 & 74 & 489 & 78 & -4 \\
\hline
\end{tabular}

$* * *, * *$, and $*$ denote statistical significance at the $1 \%, 5 \%$ and $10 \%$ levels, respectively. 


\section{TABLE 5 \\ BIDDERS WITH AT LEAST ONE OF THE SAME TOP TWO EXECUTIVES IN YEAR $t$ and YEARS $t-3$ to $t+3$}

\begin{tabular}{|c|c|c|c|c|c|}
\hline & \multicolumn{2}{|c|}{ White Knights } & \multicolumn{2}{|c|}{ Hostile Bidders } & \multirow{2}{*}{$\begin{array}{c}\% \text { Difference } \\
\% \%\end{array}$} \\
\hline & $\mathbf{N}$ & $\%$ & $\mathbf{N}$ & $\%$ & \\
\hline $\mathbf{t}-\mathbf{3}$ & 549 & $87 \%$ & 562 & $89 \%$ & -2 \\
\hline $\mathbf{t}-\mathbf{2}$ & 574 & 91 & 587 & 93 & -2 \\
\hline $\mathbf{t}-\mathbf{1}$ & 625 & 99 & 612 & 97 & $-2 * *$ \\
\hline $\mathbf{t}+\mathbf{1}$ & 600 & 95 & 606 & 96 & -1 \\
\hline $\mathbf{t}+2$ & 568 & 90 & 568 & 90 & 0 \\
\hline $\mathbf{t}+\mathbf{3}$ & 568 & 90 & 524 & 83 & 7 \\
\hline
\end{tabular}

Since this group of firms has inefficient managers as measured in the year before the takeover year, shareholders may not wait until the acquisition but rather may replace management immediately before the acquisition. Whether these new top executives have had the chance to establish a record of investing in positive NPV projects is debatable. However, their acquisition decision is a negative NPV investment decision. We indicate the number of top executives replaced in years t-1 through $t+3$ in row 3 of Table 6 and find that $204(52 \%)$ of all inefficient top executives are replaced immediately before or following the acquisition. However, only $55(14 \%)$ are replaced from outside the existing management team. We find that there is a tendency to replace inefficient top executives with another member of the same inefficient management team. Of the 133 replacement top executives in years $t$ and $t-1,31$ are from outside the firm, and 102 are from inside the firm and proceed to make a negative NPV acquisition. Thus, arguing that managerial inefficiency leads to top executives losing their position is difficult to support, and our results are consistent with entrenched management.

TABLE 6

\section{BIDDERS SEPARATED BY MANAGERIAL EFFICIENCY WITH DIFFERENT TOP EXECUTIVES IN YEARS $\mathrm{t}+1$ to $\mathrm{t}+3$}

\begin{tabular}{|c|c|c|c|c|c|c|c|c|}
\hline \multicolumn{4}{|l|}{$-\mathrm{CAR}, \mathrm{q}<1$} & \multicolumn{5}{|c|}{$-\mathrm{CAR}, \mathrm{q}>1$} \\
\hline Years & $\begin{array}{l}\text { Number } \\
\text { Different } \\
\text { from Top } \\
\text { Exec in } \\
\text { Year } t\end{array}$ & $\%$ & $\begin{array}{l}\text { Number } \\
\text { not in Top } \\
2 \text { in Year } t\end{array}$ & $\%$ & $\begin{array}{l}\text { Number } \\
\text { Different } \\
\text { from Top } \\
\text { Exec in } \\
\text { Year } t\end{array}$ & $\%$ & $\begin{array}{l}\text { Number } \\
\text { not in } \\
\text { Top } 2 \text { in } \\
\text { Year } t\end{array}$ & $\%$ \\
\hline$t+1, t+2, t+3$ & 71 & $18 \%$ & 24 & $6 \%$ & 50 & $35 \%$ & 14 & $10 \%$ \\
\hline$t+1, t+2$ & 55 & 14 & 24 & 6 & 43 & 30 & 14 & 10 \\
\hline$t-1, t, t+1, t+2, t+3$ & 204 & 52 & 55 & 14 & 72 & 50 & 14 & 10 \\
\hline$t-1, t, t+1, t+2$ & 189 & 48 & 55 & 14 & 64 & 45 & 14 & 10 \\
\hline Sample Size & 393 & & & & 143 & & & \\
\hline
\end{tabular}

Below, we draw comparisons between the white knights with q values greater than one and negative CAR values. Shareholders may be more likely to act when they are accustomed to value-increasing investment decisions. Fifty (35\%) of the 143 firms with complete data replaced their top executives in the three years following the acquisition. However, only 14 firms $(10 \%)$ replaced their top executive from outside their existing management team. Replacing a top executive with an insider may be in the shareholders' interest since the management team makes positive NPV decisions $(q>1)$ and inside officers are familiar with the company. The percentage of replacements for this group is higher than that 
for white knights whose management teams are inefficient. Thus, shareholders occasionally replace top executives who make value-decreasing investment decisions. However, for firms with inefficient management, we do not observe a strong tendency for shareholders to replace existing management with outsiders. Our findings are consistent with Jensen and Meckling's (1976) idea that the investment decisions of entrenched management are made in the management's interests rather than to enhance shareholder wealth.

In addition to bivariate tests, we conducted the following LOGIT regression in a procedure similar to that of Powers (2005).

$Y_{j}=a_{0}+a_{1} X_{1 j}+a_{2} X_{2 j}+a_{3} X_{3 j}+\varepsilon_{j}$

where

$Y_{j}=a$ binary variable with a value of 1 when the firm replaces the executive team,

$\mathrm{X}_{1 \mathrm{j}}=$ dollar value of residual return,

$X_{2 j}=a$ binary variable with a value of 1 if the bidder has a $q$ less than one,

$\mathrm{X}_{3 \mathrm{j}}=\mathrm{a}$ binary interaction variable with a value of 1 if the bidder has both a negative abnormal return and a $q$ less than one.

Regressions with different measures of executive replacement as the dependent variable provided similar results. These variables included whether the top executive was replaced in each of the three years following the takeover bid, whether the board replaced the top executive with an insider or an outsider, and whether the board replaced either of the top two executives. None of the coefficients were significant, which reconfirms our belief that neither a takeover attempt nor another negative NPV investment decision by a top executive who makes value-decreasing investment decisions leads to an executive's job loss.

In summary, managerial efficiency is one factor that distinguishes white knights from hostile bidders. On average, white knights have $\mathrm{q}$ ratios less than one and earn negative abnormal returns when they bid for the target firm, whereas hostile bidders have average q ratios that are not significantly different from one and earn positive abnormal returns with their initial bid for the target. Also, high q bidders either significantly earn more or lose less than low q bidders. High q white knights lose less than low q white knights, and high q hostile bidders gain more than low q hostile bidders.

The managers of white knight firms who make negative NPV decisions are not inexperienced. Relatively few new top executives are observed, and the newly elected tend to be promoted from the number two executive position. In addition, the experience levels of white knight management teams are similar to those of hostile bidders, and hostile bidders make value-enhancing investment decisions. Among those white knights with management teams that make positive NPV investment decisions, inexperience in the top executive position cannot explain why these executives make bids that are not in their shareholders' interest. Among white knights with management teams who do not make valueincreasing investment decisions, even when they bid for targets via large and highly visible valuedecreasing investment decisions, a tendency to replace these managers is not observed. However, among white knights with managers who make positive NPV investment decisions but who also make a highly visible value-decreasing investment decision when they bid for the target, a limited tendency to replace the top executive is observed, and the replacement is frequently the executive second in command.

\section{CONCLUSIONS}

In conclusion, white knights overbid for the target while hostile bidders in white knight contests make initial bids that enhance their shareholders' value. We explore one possible reason for this discrepancy in managerial efficiency. We find that white knights that enter late in the contest after an initial bid by another bidder must enter with a high bid since another bid is already on the table. Why do some firms decide to bid late in the contest while others do not? Why do some firms decide to bid as white knights and others do not? Presumably, those that do not bid do so because their bid would be a negative NPV 
project. Those firms (white knights) who decide to bid earn negative abnormal returns, which suggests that they would have been better off if they decided not to bid. We find that white knight managers made bad investment decisions before their decision to bid for the target and are less efficient managers than hostile bidders.

White knights have historically overinvested, and their entry into the control contest is just one more negative NPV decision. However, hostile bidders have a history of making positive NPV investment decisions, and their bid for the target is another good investment decision. Making positive NPV investments in the past does not ensure that hostile bidders have made good investment decisions in the past; instead, the market perceives that the bid for the target is a good investment. Thus, the management teams of hostile bidders select targets and bids that will enhance the value of their firms. However, white knight management teams are inefficient because they have not consistently made value-enhancing investment decisions, and the acquisition is just one more negative NPV investment.

The results indicate that the value-decreasing investment decision to acquire a target may be a "mistake." Although white knights may make value-decreasing bids, such bids may be an aberration in an otherwise consistent record of making value-enhancing investment decisions. Of the white knights we examined, $210(33 \%)$ have management teams that make good investment decisions. Of these 210 firms, only 67 made value-enhancing initial bids for their targets, whereas the other 143 may have inside information that the target is more valuable than the market perceives, or they may have overestimated the target's value and bid too much. Also, 21 firms did not have the opportunity to reassess their initial bid because the hostile bidder did not make a counter bid. However, of the 49 firms that had the opportunity to withdraw, 21 did not choose to continue in the bidding. Also, among the firms with managers who normally made good investment decisions but who made an apparent value-decreasing bid for the target, a tendency to replace the top executive in the year(s) following the acquisition or acquisition attempt was observed.

We obtain evidence indicating many white knights may have entrenched management teams. Most of the white knight management teams have made value-decreasing investment decisions before their initial bid for the target. Of these 407 management teams, 393 made initial bids resulting in losses for their shareholders, with significant negative abnormal returns. These management teams are not primarily inexperienced managers. Also, only a slight tendency to replace these managers following their highly visible, value-destroying investment decision to acquire the target is observed. Shareholders either cannot replace these management teams or choose not to.

\section{REFERENCES}

Andrade, G., Mitchell, M. L., \& Stafford, E. (2001). New evidence and perspectives on Mergers. Journal of Economic Perspectives, 15, 103-120. doi:10.1257/jep.15.2.103.

Ang, J. S., \& Zhang, S. (2004). An evaluation of testing procedures for long-horizon event studies. Review of Quantitative Finance and Accounting, 23, 251-274. doi:10.1023/B:REQU.0000042344.27369.0d.

Banerjee, A., \& Owers, J. E. (1992). Wealth reduction in white knight bids. Financial Management, 21, 48-57. doi:10.2307/3666018.

Banerjee, A., \& Owers, J. E. (1993). Managerial incentives and corporate control auctions. Managerial and Decision Economics, 14, 295-309. doi:10.1002/mde.4090140403.

Betton, S., Eckbo, B. E., \& Thorburn, K. S. (2008). Merger negotiations and the Toehold Puzzle. Journal of Financial Economics, 91, 158-178. doi:10.1016/j.jfineco.2008.02.004.

Bollerslev, T. (1986). Generalized autoregressive conditional heteroskedasticity. Journal of Econometrics, 31, 307-327. doi:10.1016/0304-4076(86)90063-1.

Boone, A. L., \& Mulherin, J. H. (2008). Do auctions induce a winner's curse? New evidence from the corporate takeover market. Journal of Financial Economics, 89, 1-19. doi:10.1016/j.jfineco.2007.08.003. 
Bradley, M., Desai, A., \& Kim, E. H. (1988). Synergistic gains from corporate acquisitions and their division between the stockholders of target and acquiring firms. Journal of Financial Economics, 21, 3-40. doi:10.1016/0304-405X(88)90030-X.

Brockett, P. L., Chen, H.-M., \& Garven, J. R. (1999). A new stochastically flexible event methodology with application to proposition 103. Insurance: Mathematics and Economics, 25, 197-217. doi:10.1016/S0167-6687(98)00046-8.

Carroll, C., Griffith, J. M., \& Rudolph, P. M. (1998). The performance of white-knight management. Financial Management 27, 46-56. doi:10.2307/3666292.

Ciscel, D. H., \& Carroll, T. M. (1980). The determinants of executive salaries: an econometric survey. The Review of Economics and Statistics, 62, 7-13. doi:10.2307/1924267.

Corhay, A., \& Rad, A. T. (1996). Conditional heteroskedasticity adjusted market model and an event study. The Quarterly Review of Economics and Finance, 36, 529-538. doi:10.1016/S10629769(96)90050-2.

Demerjian, P., Lev, B., \& McVay, S. (2012). Quantifying managerial ability: A new measure and validity tests. Management Science. 58, 1229-1248. doi:10.1287/mnsc.1110.1487.

Dennis, D. K.. \& McConnell, J. J. (1986). Corporate mergers and security returns. Journal of Financial Economic,s 16, 143-187. doi:10.1016/0304-405X(86)90059-0.

Eckbo, B. E. (2009). Bidding strategies and takeover premiums: a revie. Journal of Corporate Finance, 15, 149-178. doi:10.1016/j.jcorpfin.2008.09.016.

Engle, R. F. (1982). Autoregressive conditional heteroscedasticity with estimates of the variance of United Kingdom inflation. Econometrica, 50, 987-1008. doi:10.2307/1912773.

Engle, R. (2001). GARCH 101: the use of ARCH/GARCH models in Applied Econometrics. Journal of Economic Perspectives, 15, 157-168. doi:10.1257/jep.15.4.157.

Fich, E. M., \& Shivdasani, A. (2006). Are busy boards effective monitors? Journal of Finance, 61, 689724. doi:10.1111/j.1540-6261.2006.00852.x.

Hasbrouck, J. (1985). The characteristics of takeover targets and other measures. Journal of Banking \& Finance, 9, 351-362. doi:10.1016/0378-4266(85)90038-X.

Jensen, M. C., \& Meckling, W. H. (1976). Theory of the firm: managerial behavior, agency costs and ownership structure. Journal of Financial Economics, 3, 305-360. doi:10.1016/0304405X(76)90026-X.

Kaplan, S. N., \& Weisbach, M. S. (1992). The success of acquisitions: evidence from divestitures. The Journal of Finance, 47, 107-138. doi:10.1111/j.1540-6261.1992.tb03980.x.

Kini, O., Kracaw, W., \& Mian, S., 2004, The nature of discipline by corporate takeovers. Journal of Finance, 59, 1511-1552. doi:10.1111/j.1540-6261.2004.00671.x.

Kothari, S. P., \& Warner, J. B. (1997). Measuring long-horizon security price performance. Journal of Financial Economics, 43, 301-339. doi:10.1016/S0304-405X(96)00899-9.

Lang, L. H. P., \& Stulz, R. M. (1994). Tobin's q, Corporate Diversification and Firm Performance. Journal of Political Economy, 102, 1248-1280. doi:10.1086/261970.

Lang, L. H. P., Stulz, R. M., \& Walkling, R. A. (1989). Managerial performance, Tobin's q, and the gains from successful tender offers. Journal of Financial Economics, 24, 137-154. doi:10.1016/0304405X(89)90075-5.

Lang, L. H. P., Stulz, R., \& Walkling, R. A. (1991). Journal of Financial Economics, 29, 315-335. doi:10.1016/0304-405X(91)90005-5.

Malmendier, U., \& Tate, G. (2008). Who makes acquisitions? CEO overconfidence and the market's reaction. Journal of Financial Economics, 89, 20-43. doi:10.1016/j.jfineco.2007.07.002.

Mann, H. B., \& Whitney, D. R. (1947). On a test of whether one of two random variables is stochastically larger than the other. Annals of Mathematical Statistics, 18, 50-60. doi:10.1214/aoms/1177730491.

Moeller, S. B., Schlingemann, F. P., \& Stulz, R. M. (2005). Wealth destruction on a massive scale? A study of acquiring $\square$ firm returns in the recent merger wave. Journal of Finance, 60, 757-782. doi:10.1111/j.1540-6261.2005.00745.x. 
Niden, C. M. (1993). An empirical examination of white knight corporate takeovers: synergy and overbidding. Financial Management, 22, 28-45. doi:10.2307/3665575.

Papadakis, V. M., \& Thanos, I. C. (2010). Measuring the performance of acquisitions: an empirical investigation using multiple criteria. British Journal of Management, 21, 859-873. doi:10.1111/j.1467-8551.2009.00671.x.

Perfect, S. B., \& Wiles, K. W., 1994, Alternative constructions of Tobin's q: an empirical comparison. Journal of Empirical Finance, 1, 313-341. doi:10.1016/0927-5398(94)90007-8.

Powers, E. A. (2005). Interpreting logit regressions with interaction terms: an application to the management turnover literature. Journal of Corporate Finance, 11, 504-522. doi:10.1016/j.jcorpfin.2004.08.003.

Roll, R. (1986). The hubris hypothesis of corporate takeovers. Journal of Business, 59, 197-216. doi:10.1086/296325.

Schwert, G. W. (2000). Hostility in takeovers: in the eyes of the beholder? The Journal of Finance, 55, 2599-2640. doi:10.1111/0022-1082.00301.

Servaes, H. (1991). Tobin's q and the gains from takeovers. Journal of Finance, 46, 409-419. doi:10.1111/j.1540-6261.1991.tb03758.x.

Smiley, R. H., \& Stewart, S. D. (1985). White Knights and takeover bids. Financial Analysts Journal, 41, 19-26. doi:10.2469/faj.v41.n1.19.

Sudarsanam, S., \& Mahate, A. A. (2006). Are friendly acquisitions too bad for shareholders and managers? Long $\square$ term value creation and top management turnover in hostile and friendly acquirers. British Journal of Management, 17, S7-S30.

Thaler, R. H. (1988). Anomalies: the winner's curse. Journal of Economic Perspectives, 2, 191-202. doi:10.1257/jep.2.1.191.

Wright, P., Kroll, M., \& Elenkov, D. (2002). Acquisition returns, increase in firm size, and chief executive officer compensation: the moderating role of monitoring. Academy of Management Journal, 45, 599-608. 